\title{
Malignancy and survival in dermatitis herpetiformis: a comparison with coeliac disease
}

\author{
P Collin, E Pukkala, T Reunala
}

\begin{abstract}
Background-Dermatitis herpetiformis is a lifelong, gluten sensitive skin disease. Patients with dermatitis herpetiformis, similar to patients with coeliac disease not adhering to a gluten free diet, seem to have increased risk for lymphoma.

Aims-This study looked at the occurrence of malignancy and survival of patients with dermatitis herpetiformis and compared the results with those seen in patients with coeliac disease or in the general population.
\end{abstract}

Patients-A total of 305 adult patients with dermatitis herpetiformis diagnosed at the University Hospital of Tampere in 1970-1992 were studied. Most patients started a gluten free diet and at the end of the study $93 \%$ of the patients were adhering to the diet. A control group comprised 383 adult patients with coeliac disease, $81 \%$ of them adhered to a gluten free diet, $6 \%$ had a normal diet, and in $13 \%$ the diet history remained unknown.

Methods-The occurrence of malignant diseases and survival of the patients were assessed up to the end of 1993. Standardised incidence ratios (SIR) with $95 \%$ confidence intervals were used for the malignant diseases. The survival of the patients was compared with that of the general population.

Results-Thirteen (4.3\%) patients with dermatitis herpetiformis developed 14 malignant disorders during the follow up (SIR $1 \cdot 25 ; 95 \%$ confidence intervals 0.68 to 2.09). A non-Hodgkin's lymphoma occurred in four patients with dermatitis herpetiformis, significantly more than expected (SIR 10.3; 2.8-26.3). Thirteen $(4 \cdot 3 \%)$ patients with dermatitis herpetiformis died during the follow up but there was no increased general mortality. In coeliac disease, $13(3.4 \%)$ patients developed malignancy (SIR 1.16; 0.62 to 1.97 ), $31(8 \cdot 1 \%)$ patients died but the survival rate did not differ from that in the general population.

Conclusions-The incidence of nonHodgkin's lymphoma was significantly increased in patients with dermatitis herpetiformis. The results also confirm that the patients with dermatitis herpetiformis treated mainly with a gluten free diet have no increased general mortality.

(Gut 1996; 38: 528-530)

Keywords: dermatitis herpetiformis, coeliac disease, gluten free diet, lymphoma.
Dermatitis herpetiformis (DH) is a lifelong, gluten sensitive blistering skin disease that can be controlled by dapsone. ${ }^{12}$ Gastrointestinal symptoms are rare in $\mathrm{DH}$, but about $80 \%$ of patients have villous atrophy and the remaining patients show increased amounts of gamma/ delta receptor bearing $T$ lymphocytes in the jejunal mucosa. ${ }^{3}$ The enteropathy and in all patients with $\mathrm{DH}$ also the rash heals slowly with a gluten free diet and relapses when the diet is withdrawn. ${ }^{45}$ This suggests that $\mathrm{DH}$ is specific cutaneous manifestation of coeliac disease. Evidence of this is further strengthened by immunogenetic and family studies. These have shown that almost all patients with $\mathrm{DH}$ have the 'coeliac' HLA alleles DQA1 ${ }^{\star} 0501$ and $\mathrm{DQB} 1{ }^{\star} 0201,{ }^{6}$ and that the first degree relatives and even monotsygotic twin pairs of patients with $\mathrm{DH}$ frequently contract coeliac disease. ${ }^{7}$

In coeliac disease, an increased risk of malignancy and increased general mortality have been found in a British ${ }^{8}$ but not in a recent Finnish study. ${ }^{9}$ In $\mathrm{DH}$, an increased incidence of malignancy and especially of lymphoma has been reported in studies from England ${ }^{1011}$ and Sweden. ${ }^{12}$ In the Swedish study no data were available on the treatment given to the patients. Moreover, the British series included $\mathrm{DH}$ patients taking a gluten containing diet, which has been shown to increase the incidence of malignancy in patients with coeliac disease. ${ }^{8}$

In this study, we examined the occurrence of malignancy and survival in a $\mathrm{DH}$ patient cohort treated mainly with a gluten free diet. The findings were compared with those in patients with coeliac disease to find out whether there are any differences between these two closely associated gluten sensitive diseases. The occurrence of malignancy and survival was compared also with the general population.

\section{Methods}

\section{Patients}

The study cohort included all 305 consecutive patients with $\mathrm{DH}$ diagnosed at the Department of Dermatology, Tampere University Hospital, in 1970-1992. The diagnosis of $\mathrm{DH}$ was based on the clinical picture and on the finding of pathognomic granular IgA deposits in the epidermal-dermal junction by direct immunofluorescence examination. Small bowel biopsy specimens were taken from $237(78 \%)$ patients with $\mathrm{DH}$ and the findings were graded as subtotal or partial villous atrophy and as normal mucosa. The patients were prescribed dapsone and most patients adhered to a gluten free diet at the same time. Since 1978, the patients with $\mathrm{DH}$ were routinely followed up at 
TABLE I Mean age, sex distribution, and duration of follow up of the patients with dermatitis herpetiformis and coeliac disease

\begin{tabular}{lcc}
\hline & $\begin{array}{l}\text { Dermatitis } \\
\text { herpetiformis }\end{array}$ & $\begin{array}{l}\text { Coeliac } \\
\text { disease }\end{array}$ \\
\hline Patients (n) & 305 & 383 \\
Males & 161 & 103 \\
Females & 144 & 280 \\
Male/female ratio & $1 \cdot 12$ & $0 \cdot 37$ \\
Mean age at diagnosis & $40.4(11-81)$ & $41 \cdot 8(16-78)$ \\
(range) & $39 \cdot 1$ & 43.5 \\
Males & 41.5 & $41 \cdot 1$ \\
Females & 3029 & 3107 \\
Person years at risk & 9.9 & $8 \cdot 1$ \\
Mean follow up time & & \\
\hline
\end{tabular}

${ }^{\star}$ Patients were entered into the study during 1970-1992 and followed up to the end of 1993

a special outpatient clinic for three years or longer to check the efficacy of gluten free diet on the rash as previously described. ${ }^{5}$ In 1992-1993 a special investigation regarding the gluten free diet was made among those 76 patients with $\mathrm{DH}$ who were alive but did not attend regular follow up.

The cohort with coeliac disease included all 383 patients diagnosed at the Department of Medicine, Tampere University Hospital in 1970-1992. The diagnosis of coeliac disease was based on the characteristic histological findings of subtotal or severe partial villous atrophy and crypt hyperplasia in small bowel biopsy specimens. All patients were prescribed a gluten free diet, and since 1980 they were requested to have a control jejunal biopsy after 6-12 months. The dietary history of patients with coeliac disease was assessed at the time of control biopsy.

\section{Malignancy and survival}

The follow up of malignancy and survival started at the date of diagnosis of $\mathrm{DH}$ or coeliac disease, and the closing date was 31 December 1993. The follow up of malignancy was made through the files of the Finnish Cancer Registry and that of death through the Statistics Finland. The observed numbers of malignant diseases were compared with those expected on the basis of the age and sex specific incidence rates among the Finnish population. The $95 \%$ confidence intervals for the standardised incidence ratios (SIR) were estimated under the assumption that the observed numbers of malignant disorders followed a Poisson distribution. Annual cumulative relative survival rates were calculated for the male and female patients separately.

TABLE II Observed and expected numbers of malignant diseases and standardised incidence ratios (SIR) with $95 \%$ confidence intervals (95\% CI) among patients with dermatitis herpetiformis and coeliac disease in 1970-93, by disease and site

\begin{tabular}{lcccc}
\hline Primary site & Observed & Expected & SIR & $95 \%$ CI \\
\hline Dermatitis herpetiformis & 14 & 11.2 & & \\
$\quad$ All sites & 2 & 0.7 & 1.25 & 0.68 to 2.09 \\
Stomach & 3 & 1.0 & 3.86 & 0.35 to 10.3 \\
Colon and rectum & 4 & 0.4 & 10.3 & 0.63 to 8.95 \\
$\quad$ Lymphoma (any site) & 13 & 11.2 & $1 \cdot 16$ & 0.62 to 1.97 \\
Coeliac disease & 0 & 0.6 & 0 & 0.00 to $6 \cdot 18$ \\
All sites & 0 & 0.9 & 0 & 0.00 to 3.97 \\
Stomach & 1 & 0.4 & 2.66 & 0.07 to 14.8 \\
Colon and rectum & & & & \\
Lymphoma (any site) & & &
\end{tabular}

${ }^{\star} \mathrm{p}<0.01$.

\section{Results}

Age, sex, and adherence to a gluten free diet Altogether 305 patients with $\mathrm{DH}$ and 383 patients with coeliac disease were diagnosed during 1970-1992. The mean age at diagnosis was 40.4 years in $\mathrm{DH}$ and 41.8 years in coeliac disease (Table I). The male/female ratio was 1.12 in $\mathrm{DH}$ and 0.37 in coeliac disease, which is a significant difference $\left(\mathrm{p}<0.01 ; \chi^{2}\right.$ test).

Small bowel biopsy showed subtotal villous atrophy in $100(42 \%)$, partial villous atrophy in $77(33 \%)$, and normal mucosa in $60(25 \%)$ patients with $\mathrm{DH}$. Of the 305 patients, 244 $(80 \%)$ started a gluten free diet after the diagnosis. The reasons for unwillingness to start a gluten free diet were old age, travelling because of work, high cost of the diet or military service. At the end of the follow up, treatment data were available on 273 patients who were alive. Of these patients, 251 (93\%) adhered to a gluten free diet. The response to the diet treatment was good; $118(47 \%)$ patients had been able to stop using dapsone, $95(38 \%)$ patients had reduced the daily dose of dapsone by $50 \%$ or more, and only $38(15 \%)$ patients had been unable to reduce the daily dose of dapsone during the diet treatment.

Of the 383 patients with coeliac disease, 312 $(81 \%)$ adhered to a gluten free diet, $23(6 \%)$ were taking a normal diet, and the diet history remained unknown in $48(13 \%)$ patients. A control small bowel biopsy was performed on 290 patients during the gluten free diet treatment. Mucosal recovery was seen in $90 \%$ of these patients, which confirmed that these patients adhered strictly to the diet.

\section{Malignancy}

During the follow up 14 malignant diseases occurred in 13 patients with $\mathrm{DH}$ and 13 disorders in 13 patients with coeliac disease (Table II). The expected number was 11.2 for both groups and the SIR was 1.25 (95\% CI 0.68 to 2.09 ) for patients with $\mathrm{DH}$ and 1.16 $(0.62$ to 1.97$)$ for patients with coeliac disease. The only significant SIR $(10 \cdot 3 ; 95 \%$ CI $2 \cdot 80$ to 26.3) was that for non-Hodgkin's lymphoma among patients with DH (Table II).

Table III shows all malignant diseases occurring both before and after the diagnosis of $\mathrm{DH}$. Four patients with $\mathrm{DH}$ contracted malignancy before the diagnosis. One patient with $\mathrm{DH}$ contracted two malignant diseases during the follow up: prostatic cancer and penile lymphoma. Six of 13 patients with $\mathrm{DH}$ who contracted a malignancy during the follow up were taking a normal diet and seven patients were adhering to a gluten free diet (Table III).

\section{Survival}

Thirteen (4.3\%) patients with $\mathrm{DH}$ and 31 $(8 \cdot 1 \%)$ with coeliac disease died during the follow up period. The 10 and 15 year survival rates of both female and male patients with DH tended to exceed those of the general population (Table IV). The survival rates of the patients with coeliac disease did not differ 
TABLE III Malignant diseases in patients with dermatitis herpetiformis

\begin{tabular}{|c|c|c|c|c|c|}
\hline \multicolumn{3}{|c|}{ Dermatitis herpetiformis } & \multicolumn{2}{|c|}{ Malignancy } & \multirow{2}{*}{$\begin{array}{l}\text { Survival status/ } \\
\text { age at the end } \\
\text { of follow up }\end{array}$} \\
\hline $\begin{array}{l}\text { Age at } \\
\text { diagnosis }\end{array}$ & $\begin{array}{l}\text { fejunal } \\
\text { biopsy }\end{array}$ & $\begin{array}{l}\text { Gluten free } \\
\text { diet }\end{array}$ & $\begin{array}{l}\text { Age at } \\
\text { diagnosis }\end{array}$ & Site & \\
\hline $\begin{array}{l}68 \\
79 \\
\text { Females } \\
38 \\
46 \\
56 \\
64 \\
69 \\
70 \\
76\end{array}$ & $\begin{array}{l}\text { SVA } \\
\text { PVA } \\
\text { NK } \\
\text { NK } \\
\text { NK } \\
\text { PVA } \\
\text { NK } \\
\text { PVA } \\
\text { SVA } \\
\text { NK } \\
\text { PVA } \\
\text { SVA } \\
\text { NK } \\
\text { N } \\
\text { NK } \\
\text { NK } \\
\text { NK }\end{array}$ & $\begin{array}{l}+ \\
+ \\
+ \\
- \\
- \\
- \\
- \\
+ \\
+ \\
-\end{array}$ & $\begin{array}{l}36^{\star} \\
37 \\
60^{\star} \\
66 \\
71^{\star} \\
74 \\
78 \\
78 \\
79 \\
79 \\
84 \\
41 \\
50 \\
57 \\
68 \\
70 \\
73 \\
64^{\star}\end{array}$ & $\begin{array}{l}\text { Lymphoma† } \\
\text { Lymphoma† } \\
\text { Stomach } \\
\text { Chronic lymphatic leukaemia } \\
\text { Prostate } \\
\text { Multiple myeloma } \\
\text { Lung } \\
\text { Prostate } \\
\text { Lymphoma } \\
\text { Colon } \\
\text { Rectum } \\
\text { Lymphoma† } \\
\text { Kidney } \\
\text { Stomach } \\
\text { Lymphoma† } \\
\text { Stomach } \\
\text { Breast } \\
\text { Tongue }\end{array}$ & $\begin{array}{l}\text { Died/50 } \\
\text { Alive/51 } \\
\text { Alive/64 } \\
\text { Died/67 } \\
\text { Died/80 } \\
\text { Died/76 } \\
\text { Died/79 } \\
\text { Alive/80 } \\
\text { Alive/81 } \\
\text { Died/87 } \\
\\
\text { Alive/55 } \\
\text { Alive/52 } \\
\text { Alive/60 } \\
\text { Died/69 } \\
\text { Died/71 } \\
\text { Alive/83 } \\
\text { Alive/77 }\end{array}$ \\
\hline
\end{tabular}

SVA = subtotal, PVA= partial villous atrophy, $\mathrm{N}=$ normal mucosa, $\mathrm{NK}=$ not known

$\star=$ malignancy before diagnosis of dermatitis herpetiformis. $\dagger=$ non-Hodgkin's lymphoma.

significantly from the rates seen in the general population.

\section{Discussion}

In this study, a cohort of 305 patients with $\mathrm{DH}$ sampled during 23 years was examined for malignancy and survival. The patient series is larger than any previous study from one centre and none of the patients were lost to follow up. We were also able to compare the results with those seen in 383 patients with coeliac disease.

In contrast with the present results, a fourfold increased cancer incidence was found in a recent study of $152 \mathrm{DH}$ patients followed up in London in 1971-1985. ${ }^{10}$ One reason for the discrepancy could be the differences in the treatment. In our study, $93 \%$ of the $\mathrm{DH}$ patients were treated with a gluten free diet compared with $38 \%$ of the British patients. These findings imply that similar to coeliac disease, ${ }^{8}$ gluten free diet also seems to protect against the development of malignancy in $\mathrm{DH}$ patients.

Two previous studies in $\mathrm{DH}$ have shown 100-fold and 5.4-fold risks of developing lymphoma. ${ }^{11} 12$ We found a 10 -fold, statistically significant risk based on four observed cases of non-Hodgkin's lymphoma. Three of the $\mathrm{DH}$ patients were adhering to a gluten free diet, but in two patients the duration of the diet was less than five years, which is probably too short a period to play any protective part in the development of lymphoma. ${ }^{8}$ In our four patients with lymphoma, three presented with abnormal small bowel villous architecture and one patient with normal mucosa. This implies that a normal

TABLE IV Cumulative relative survival rates (CRSR) of the patients with dermatitis herpetiformis and coeliac disease

\begin{tabular}{|c|c|c|c|c|c|c|}
\hline \multirow{2}{*}{$\begin{array}{l}\text { Disease (number } \\
\text { at the beginning } \\
\text { of follow up) }\end{array}$} & \multicolumn{2}{|c|}{5 Years } & \multicolumn{2}{|c|}{10 Years } & \multicolumn{2}{|c|}{15 Years } \\
\hline & No & CRSR & No & CRSR & No & $C R S R$ \\
\hline \multicolumn{7}{|c|}{ Dermatitis herpetiformis } \\
\hline Males (161) & 135 & $101 \%(3 \cdot 2 \%)^{\star}$ & 89 & $103 \%(4 \cdot 9 \%)$ & 38 & $107 \%(6 \cdot 6 \%)$ \\
\hline Females (144) & 124 & $101 \%(2 \cdot 1 \%)$ & 82 & $103 \%(2 \cdot 9 \%)$ & 34 & $107 \%(3.0 \%)$ \\
\hline \multicolumn{7}{|l|}{ Coeliac disease } \\
\hline Males (103) & 80 & $94 \%(7 \cdot 4 \%)$ & 37 & $94 \%(10 \cdot 6 \%)$ & 14 & $90 \%(17 \cdot 7 \%)$ \\
\hline Females $(280)$ & 231 & $99 \%(2 \cdot 0 \%)$ & 110 & $99 \%(3 \cdot 6 \%)$ & 28 & $100 \%(5 \cdot 2 \%)$ \\
\hline
\end{tabular}

No $=$ number at follow up. ${ }^{\star}=2 \times$ standard error in parentheses. small bowel mucosa in DH does not protect from lymphoma. Despite this, there are two main reasons why we recommend that a small bowel biopsy specimen is taken from patients with $\mathrm{DH}$ before starting the gluten free diet treatment. Firstly, most DH patients have no gastrointestinal symptoms and therefore, their motivation to follow the diet is much better if they know that the small bowel mucosa is damaged. Secondly, if some gastrointestinal symptoms appear during the diet or if the rash does not respond adequately to the gluten free diet treatment, it is helpful to know how severely the jejunal mucosa was damaged before the diet was started. We do not routinely take control small bowel biopsy specimens from patients with $\mathrm{DH}$, because the resolution of the rash is a good indicator for strict adherence to gluten free diet treatment. In this study the dermatological outcome was good and similar to that reported in a previous British study. ${ }^{13}$ Half of our patients with $\mathrm{DH}$ could stop using dapsone and one third of the patients could significantly reduce the daily dose of dapsone during the gluten free diet treatment.

The general mortality of our patients with $\mathrm{DH}$ was not increased, a result that is in agreement with that reported by Swerdlow et al. ${ }^{10}$ The longterm survival rates of our patients with $\mathrm{DH}$ were slightly but significantly higher than those of the general population. One reason for this could be that the patients adhered strictly to a gluten free diet and visited regularly a special outpatient clinic.

In conclusion, this study showed that the patients with $\mathrm{DH}$ had a significantly increased incidence of non-Hodgkin's lymphoma. The overall incidence of other malignant diseases was not increased, however, and there was no increased general mortality.

We are grateful to Bengt Söderman, System Analyst of the Finnish Cancer Registry, for performing the survival analysis and to Mrs Marianne Karsten for excellent secretarial help.

1 Alexander JO'D. Dermatitis herpetiformis. London: WB Saunders, 1975.

2 Gawkrodger DJGA, Blackwell JN, Gilmour HM, Rifkind EA, Heading RC, Barnetson RStC. Dermatitis herpetiformis: diagnosis, diet and demography. Gut 1984; 25: 151-7.

3 Savilahti E, Reunala T, Mäki M. Increase of lymphocytes bearing the $\gamma / \delta \mathrm{T}$ cell receptor in the jejunum of patients with dermatitis herpetiformis. Gut 1992; 33: 206-11.

4 Fry L, Seah PP, Riches DJ. Clearance of skin lesions in dermatitis herpetiformis after gluten withdrawal. Lancet matitis herpetiform

5 Reunala T, Blomqvist $\mathrm{K}$, Tarpila S, Halme H, Kangas $\mathrm{K}$. Gluten-free diet in dermatitis herpetiformis. I. Clinical response of 81 patients. Br $\mathcal{F}$ Dermatol 1977; 97: 473-80.

6 Fronek Z, Cheung MM, Hanbury AM, Kagnoff MF Molecular analysis of HLA DP and DQ genes associated with dermatitis herpetiformis. F Invest Dermatol 1991; 97: 799-802.

7 Reunala T, Mäki M. Dermatitis herpetiformis: a genetic disease. Eur f Dermatol 1993; 3: 519-26.

8 Holmes GKT, Prior P, Lane MR, Pope D, Allan RN. Malignancy in coeliac disease - effect of a gluten free diet. Gut 1989; 30: 333-8.

9 Collin P, Reunala T, Pukkala E, Laippala P, Keyriläinen O, Pasternack A. Coeliac disease: associated disorders and Pasternack A. Coeliac disease:
survival. Gut 1994; 35: 1215-8.

10 Swerdlow AJ, Whittaker S, Carpenter LM, English JSC. Mortality and cancer incidence in patients with dermatitis herpetiformis: a cohort study. $\mathrm{Br} \mathcal{F}$ Dermatol 1993; 129: 140-4.

11 Leonard JN, Tucker WFG, Fry JS, Coulter CAE, Boylston $\mathrm{AW}, \mathrm{McMinn} \mathrm{RMH}$, et al. Increased incidence of malignancy in dermatitis herpetiformis. $B M \mathcal{F} 1983 ; 286: 16-8$.

12 Sigurgeirsson B, Agnarsson BA, Lindelöf B. Risk of lymphoma in patients with dermatitis herpetiformis. $B M \mathcal{Y}$ 1994; 308: 13-5.

13 Garioch JJ, Lewis HM, Sargent SA, Leonard JN, Fry L. 25 years' experience of a gluten-free diet in the treatment of dermatitis herpetiformis. Br f Dermatol 1994; 131: 541-5. 